\title{
Crisis-driven reforms and local discretion: an assessment of Italy and Spain
}

\author{
SILVIA BOLGHERINI* \\ Department of Social Sciences, University of Naples Federico II, Naples, Italy
}

\begin{abstract}
The recent and still enduring global economic and financial crisis deeply impacted the institutional framework in Italy and Spain by prompting a series of reforms, which ultimately re-shaped the local government features. Based on a qualitative comparative analysis of recent reforms, the author shows that (directly and indirectly) crisis-driven provisions have significantly impacted the local levels and changed the central/local relations in both countries. During the years of crisis, a decrease in local discretion in its three main facets (fiscal, administrative, and political/functional) has taken place. This outcome could both allow for a better understanding of how central and local governments have interacted during the crisis and to contribute to the formulation of more general considerations on local discretion and central/local relations in Italy and Spain.
\end{abstract}

Keywords: local government; reform; intergovernmental relations; crisis

\section{Introduction}

Decentralization has been a major trend in Western democracies since the 1960s (Sharpe, 1979). The rise of meso-governments (Sharpe, 1993) consisted in the strengthening of intermediate levels of governments and in the expansion of political-administrative forms of decentralization. In Italy and Spain, this was particularly true during the 1980s and the 1990s (Aja, 2001, 2003; Bobbio, 2002; Baldi, 2003; Beramendi and Maiz, 2004; Nieto, 2007; Lippi, 2011). The European Union (EU) also reinforced this trend by fostering the principle of subsidiarity and the empowerment of regional and local governments.

Since the 2008 global crisis, however, concerns have been raised about the shrinking of local autonomy and self-government as a consequence of the provisions and reforms undertaken in response to the crisis. Law scholars in Italy and Spain are convinced that a new wave of re-centralization is under way (Perulli, 2010; Viver, 2011; Piperata, 2012; Mangiameli, 2013; Medina, 2014; Santamaria, 2014). Admittedly, it is no straightforward path: oscillation between localism and neo-centralism has been observed in Italy (Nanetti, 1988; Diamanti, 2003), in Spain (Maiz et al., 2010; Moreno, 2012a: 573), as well as in general (Peters et al., 2011). In Italy, it is difficult to empirically demonstrate this trend by both research data and literature, as no political actor has openly embraced or declared a policy strategy in

*E-mail: silvia.bolgherini@unina.it 
this direction and most of their statements still remain in line with the decentralization project (Gardini, 2011: 457; Bolgherini, 2014). In Spain, by contrast, the (re)centralization processes have long been under way since the early 2000s (Losada and Maiz, 2005), at least partly due to the fact that 'within the structure defined by the Spanish Constitution of 1978, two opposing processes have always co-existed (...). Specifically, the process of federalization (...) has always been accompanied by a hidden process of reactive de-federalization that has continually eroded self-government' (Maiz et al., 2010: 65). Be it a radical trend inversion or not, relations between the central and local governments have been seriously affected by the international crisis, which erupted in 2007-08, and has affected Italy and Spain most strongly after 2009.

The assumption here is that the global crisis has served as a catalyst for speeding up reforms. Some of these reforms were dictated by the need to quickly tackle the crisis. Others, such as territorial functional local government reforms, were instead part of ongoing (or at least debated) reform projects. These measures were mainly targeted at cutting costs, reducing public expenditure and tackling inefficiencies. They impacted local governments not only financially but also structurally, with effects able to re-shape central/local relations, particularly by affecting local governments' leeway. The attempt is, thus, to interpret these recent reforms in Italy and Spain within a consolidated framework, as well as to provide an assessment of the changing state of central/local relations in the two countries by focussing on local discretion.

A comparison between Italy and Spain may be particularly useful in this respect. Along with a series of traditional common features (later addressed), the two countries have displayed quite similar patterns in these years of crisis, going beyond the mere fact of belonging to the 'core' Southern family. In fact, a sort of political and economic convergence can be identified. Between 2011 and 2013, 'crisis elections' with similar features took place throughout Southern Europe (Bosco and Verney, 2012). In Italy and Spain, November 2011 saw the downfall of both governments: in Italy, Silvio Berlusconi stepped down from his fourth mandate, which he had held since 2008; in Spain, José Luis Zapatero, who had been in charge since 2004, was defeated in the 2011 snap elections. In both cases, the economic crisis was the main reason for their ousting (Bosco and Verney, 2012: 133). Both countries have paid a high political price for the economic crisis. True, their initial economic and financial conditions were different (Royo, 2009; Jones, 2012), but the end point was the same: an abrupt end to the strategy of denial and the introduction of harsh austerity measures. These conditions led both countries to initiate ambitious reform programmes, which ended almost simultaneously (late 2013 in Spain, and spring 2014 in Italy).

All levels of government have been involved in this reform process, although our analysis here will be devoted to the local level, which comprises both municipalities and second-tier authorities (provinces and forms of inter-municipal cooperations), as it is more straightforward to compare the two countries at this level. ${ }^{1}$

\footnotetext{
${ }^{1}$ Spain is divided into 17 Autonomous Communities (ACs - Comunidades Autónomas), which are the regional level, 50 provinces, and over 8000 municipalities (with their respective governments called
} 
In the next section, the theoretical framework and its focus on local discretion will be discussed. The third section seeks to clarify the distinction between directly (austerity measures) and indirectly (local government reforms) crisis-led provisions, along with an overview of the Italian and Spanish systems of local government. The fourth section deals with the expected impact of these reforms on the discretion of the local government. The penultimate section attempts to assess the validity of our expectations (and their derived propositions) by analysing the recent measures affecting local governments in Italy and Spain, limiting the assessment to qualitative and descriptive data. The final section discusses the implications of these developments.

\section{Theoretical perspective}

The 2008 global crisis and its enduring nature represent an important turning point in both Italy and Spain. Economic crises often have an impact on institutional structures, and harsher the crisis the more likely and deeper the impact, as scholars have observed during the 'political development studies' debates (Robinson, 1968). The present crisis also prompted national governments to introduce reforms, some of which derive directly from the need to meet the conditions imposed by EU economic governance agreements inaugurated after the eurozone crisis. Austerity measures belong to this group. These exogenous constraints may account for the stronger role assumed by central governments, faced with the need to respond rapidly and effectively to the crisis (Dyson, 2012, 2013; Fabbrini, 2013), although some scholars also identify incremental reform change as a response to the crisis (Moschella and Tsingou, 2013: 2-3). Other reforms, such as territorial reforms, were instead already on the national agendas and the global crisis merely accelerated their (re)start (Istituzioni del Federalismo, 2011, 2012; Irujo, 2012). Usually territorial reforms are supposed to be adopted when either local governments fail to provide effective public services (Wollmann, 2008) or when fragmentation is extremely high (Swianiewicz, 2010). Italy and Spain might be cases in point, considering the high percentage of small municipalities in these two countries (as shown later). Structural reforms such as these are usually not attempted in times of crisis (Pola, 2010; Peters et al., 2011), due to their high costs and low rewards. Yet, in both the countries, a sort of urgency-prodded

\footnotetext{
Diputaciones and Ayuntamientos). Municipalities together with second-tier authorities - that is, provinces and the inter-municipalities (Mancomunidades and Comarcas) - form the local level. Italy's sub-state levels consist of 20 regions (Regioni), 110 provinces (Province), and over 8000 municipalities (Comuni). Metropolitan cities (Città metropolitane) and the inter-municipalities form the intermediate or second-tier level together with the provinces. The municipalities and second-tier authorities form the local level. Although the Spanish ACs form at the sub-state level a more decentralised country than Italy, local levels in these two countries are highly comparable in terms of numbers, functions and competencies, bodies, and other organizational features.
} 
macro-policy window of opportunity (Keeler, 1993: 436-441) for such policies was opened up, although their final outcome is still highly uncertain.

One of the main ideas explored in this article is that direct (austerity measures) and indirect (territorial reforms) crisis-driven measures may also have structural effects on local governments, and that these effects may alter the central/local relations. It is too early to test this hypothesis in the two countries under examination, given the recent nature of these reform acts (2010 to early 2014 in Italy, and 2013 to early 2014 in Spain). A tentative investigation can, nonetheless, be carried out, with the aim of developing an interpretative framework, which encompasses the recent changes and their effects within a consolidated central/local conceptualization.

Nevertheless, some premises are in order. The approach used here does not consider party politics or ideological orientations. Although these play a crucial role in reforms, what is under examination here are the effects of reforms on central/ local relationships, rather than the inter-partisan and party politics dynamics leading to these changes.

Second, when any major crisis occurs, the shift of the decision-making power towards the central government is not surprising. This is particularly true of EU member states, due the criteria adopted by the EU governance and imposed on national governments under the supervision of the European Commission (EC). Central governments, in turn, have had to impose cuts and take on greater responsibilities for their relevant country as a whole. In other words, given the tight squeeze on public spending imposed on Italy and Spain as part of the EU's response to the crisis, central governments in these two countries were forced to act on local and regional governments' autonomy - especially that of spending money - in order to meet the demands of supranational authorities. Despite a stronger role of the central government and a reduction in local autonomy may, therefore, be expected, it is important to ascertain that this operatively happens, and how it was implemented.

The last premise is that patterns of centralization or decentralization are always context-embedded (Rhodes, 1981), and thus difficult to assess (Dente, 1985). This makes it difficult to generalize, as 'a large variety of other factors might be argued ... to affect' the degree of being local or central for a policy, a decision, or a government (Page, 1991: 2). Despite this difficulty and for the reasons mentioned in the Introduction, well-focussed comparative research on centre-local relations in Italy and Spain is particularly valuable. The literature on centre-local relations suggests that Italy and Spain share a common background as far as historical state tradition (dating back to the Napoleonic era) (Page and Goldsmith, 1987; Loughlin et al., 2010), inter-institutional relations, and power allocation (Hesse and Sharpe, 1991; Bennett, 1993; Denters and Rose, 2005) are concerned. They are also countries characterized by clientelistic system of relations (Goldsmith, 1992) and they also belong to the political localism's countries (Page, 1991). Two types of localism, where the latter is understood as 'the opportunities for local political elites to shape public services' (Page, 1991: 6), are identified: legal localism and political localism. 
Legal localism reflects the extent to which local governments can exercise control over local services and brings together the two dimensions proposed by Page and Goldsmith in 1987 and later updated in Goldsmith and Page (2010): the 'functions' of a local government and its 'discretion' in carrying them out. Political localism, in contrast, reflects the degree of influence of local political elites over national decisions affecting the local level (relying on the 'access' dimension proposed by Page and Goldsmith).

From our perspective, what matters here is 'discretion' - that is, the ability of a local authority 'as a collectivity to make decisions without the intervention of central government' (Page, 1991: 21). Local governments in Europe - Italy and Spain being no exception - experienced a long period of empowerment (Sharpe, 1993; Keating, 1998; Loughlin, 2001), which enhanced local discretion (Dente, 1985; Maiz et al., 2002; Agranoff, 2004). This situation could be directly challenged by the recent wave of reforms. It is indeed a fact that these measures, both those directly and those indirectly triggered by the crisis, have significantly altered the institutional framework of both countries, and thus influenced centre-local relations.

Although Page (1991: 21) acknowledges that there are no readily available direct indicators for discretion, surely fiscal, administrative, and functional power (although differently labelled) may arguably be recognized as cross-country indicators of local discretion (Zimmermann, 1981; Page and Goldsmith, 1985; Berman and Martin, 1988; Kersting and Vetter, 2003; Yilmaz et al., 2008; Hooghe et al., 2010).

Fiscal power relates to the extent to which local authorities are free from central financial control over incomes and expenditures. Examples of central influence include the determination of local taxes, the rules for the transfer of resources between levels of government, setting limits to current expenditure levels, prohibiting certain expenditures, or even imposing 'standard costs' for services. Administrative power refers to the degree of freedom of local governments from the involvement of the central government in detailed issues of local decisions, which coincides with Page's (1991) concept of legal regulation. This involvement may be achieved by administrative or statutory regulation. The first tool allows the central government to have a detailed involvement in local decisions also via the individual decisions of state officials, whereas statutory regulation minimizes these conditions. Under administrative regulation, the actions of local governments are constrained by the need for legally binding advance approval by the centre, whereas under statutory regulation only a posteriori validation is required. Functional (or political) power concerns a broad range of meanings, from the political setting (Yilmaz et al., 2008 ) to inter-institutional relationships (Keating, 1995), including the size of local units. ${ }^{2}$ Political/functional power will be conceived here as an indicator of local

\footnotetext{
${ }^{2}$ For the sake of completeness, it must be noted that the discussion about functional and/or political aspects of discretion often turns out to be steered by the concept of decentralization as well as overlapping with Page and Goldsmith's (1987) access dimension.
} 
discretion, in the sense that local governments may be entitled with more or less functions (Page and Goldsmith, 1987), competences, tasks, and self-organization powers. Local authorities' power to act through their functions, in defence of local interests and collectivities, is recognized - at least in the legal systems of the countries under scrutiny here - as an intrinsic element of their political autonomy. Self-organization relates not only to the territorial articulation of the system of government but also to the range of different ways of managing this.

Three empirical aspects directly concerning the above-described main indicators of local discretion - that is, respectively, fiscal, administrative, and political/ functional power - will be therefore considered: financial variations, new controls, and options for self-organization.

The first aspect (financial variations) concerns fiscal discretion, and in particular changes in budget and spending plans imposed on local authorities. Variations in financial discretion may facilitate or obstruct local discretion according to their nature and their positive or negative direction. Page (1991: 22-41) shows, however, that quantitative indicators of centralism and localism (such as spending data and state grants, usually related to fiscal discretion) are important only if viewed through the prism of the legal/political localism interconnection. The second empirical aspect (new control measures) relates to administrative discretion: when controls exerted by higher authorities are present, the directly proportional effect would be that of a limitation of local discretion. This aspect clearly reminds us of Page's concept of legal regulation. The third aspect concerns the political facet of local discretion more directly - that is, the options available to local governments in managing their own territory as well as in their decision-making processes. When an alteration in these options (i.e. an increase or decrease in their number or quality) takes place, functional discretion is likely to be altered as well.

It can be argued that the directly or indirectly crisis-led reforms and provisions have induced such changes. Therefore, the attempt here is to give an account of what the recent provisions have entailed in Italy and Spain as far as the local discretion is concerned. Taken together, these empirical aspects may allow for a better understanding of how central and local governments have interacted during the crisis, and how this has changed over time or under new conditions, most notably as a result of the recently inaugurated austerity discourse (Kamkhaji and Radaelli, 2013). It is, therefore, important to examine how these aspects of discretion have changed in recent years and to contribute to the formulation of more general considerations on local discretion and central/local relations in Italy and Spain.

\section{Directly and indirectly crisis-driven reforms}

The outbreak of the global crisis in 2007-08 marked a critical juncture both internationally and domestically for most Western countries (Cosculluela and Medina, 2012: 28). Italy and Spain have both been dramatically affected by this 
crisis, although with differing intensity, features, and reactions (Armingeon, 2012; Jones, 2012). In these years, a range of provisions were introduced in both countries with the aim of mitigating its effects. For the purposes of the present study, two very broad categories of such provisions will be identified: those directly deriving from EU compliance requirements and those that were conceived and initiated at a national level but were only indirectly influenced by the crisis. The latter category includes institutional reforms concerning the local level.

As in most crisis-hit countries, the Italian and Spanish central authorities decided to comply with the objective of balanced budgets and obliged their respective local authorities to do likewise. The EU pushed forcefully in this direction, and it can be claimed that austerity measures were imposed by the EU above all in those countries (like Italy and Spain and Greece) where any response to the crisis other than austerity plans would not have been accepted by international markets (Viver, 2011: 152). As is well known, since 2010-11, the main anti-crisis measures imposed by the EU include the implementation in its member states of the EuroPlus Pact and Sixpack, the fiscal compact and the following balanced-budget amendments, the domestically promoted spending reviews, and budget control acts (Dinan, 2012; Dickmann, 2013). In other words, this first category consisted of provisions that were established to cut public expenditure and deficits, and thus comply with EU agreements.

Provisions that were indirectly influenced by the crisis included, most prominently, attempts to rationalize the institutional and territorial arrangements of local governments. In particular, the reforms of the local government system in Italy (comprising several laws approved between 2010 and 2014, sparsely containing local government provisions, the most important being Laws 122/2010, 148/2011, 135/2012, 56/2014) and in Spain (Law 27/2013) will be considered. These reforms were put in place with the aim of curbing spending and saving money, just like the anti-crisis austerity measures described previously, but with the additional aim of tackling traditional local-level problems such as overlaps in competence, inefficiencies, municipal fragmentation, and overload. These long-standing problems were surely a stimulus to achieve greater transparency, accountability, and rationalization of tasks at the local level, where sometimes weak or ineffective governance also contributed to the above-mentioned problems.

Let us devote a few more words to the local level in both countries. Both Italy and Spain are municipally fragmented countries (Moreno, 2012b: 89): suffice to say that over $70 \%$ of municipalities in Italy and almost $84 \%$ in Spain have $<5000$ inhabitants, while 93.7 and $95 \%$, respectively, have $<20,000$ inhabitants. This of course generates issues of efficacy and efficiency, as well as overload problems for such small-sized units (Hulst and Van Montfort, 2007). For this reason, in both countries, the territorial tiers of the government targeted in recent reforms include small- and medium-sized municipalities (those with $<5000$ inhabitants in Italy and those with $<20,000$ in Spain) and the intermediate level between municipalities and regions - that is, provinces and 
inter-municipal associations. ${ }^{3}$ Provinces in Italy and Spain are simultaneously decentralized state administrations, self-governing territorial authorities, and municipal aggregations. Until 2014, the 110 Italian provinces were directly elected, whereas they are indirectly elected bodies since 2015. In Spain, provinces are traditionally indirectly elected bodies, now counting 50, and are mainly charged with municipal coordination and assistance tasks as well as the delivery of certain overmunicipal services. Municipal associations (also defined as inter-municipalities) may assume several forms in both countries but the ones addressed by the most recent reforms are the most institutionalized forms: the Municipal Unions (Unioni di comuni in Italy and Mancomunidades in Spain). These intermediate authorities are second-level indirectly elected bodies that manage transferred tasks (functions that the member municipalities decide to transfer to the Municipal Union), typically because the single municipalities are unable to manage these alone for resource reasons. There are about 400 Municipal Unions in Italy and about 1000 in Spain.

In times of crisis, both austerity measures and a trend towards re-centralization are likely to negatively impact the main aspects of local discretion. In other words, we would expect that local discretion has been reduced by these reforms. At the same time, it is interesting to observe how these changes have taken place and to analyse the means and aspects through which they have operated, as this may enable us to identify trends in centre-local relations after decades of growing local discretion.

\section{Discretion limitation: propositions and expectations}

For each indicator of local discretion (fiscal, administrative, and functional), we shall first enucleate more empirical facets of it by formulating a proposition and its relevant articulation. In the next section, we shall seek to ascertain whether the core elements of each proposition are present in a provision or reform in either or both countries. In other words, we shall assess whether the propositions hold empirically in the provisions that were driven either directly or indirectly by the crisis.

As far as the first indicator (fiscal discretion) is concerned, it was already noted that austerity measures are common in times of crisis. It is self-evident that cuts in central state financial transfers or grants to a local government may reduce their discretion, and that the greater the cuts (whether actual or planned) the more likely the shrinking of local discretion. Normative acts may also be passed to maintain local expenditure within specific limits in each annual budget. If so, we would expect local discretion to contract in line with these spending constraints, expressed as a percentage of the previous year's budget.

\footnotetext{
${ }^{3}$ In Italy, Metropolitan cities have a prominent role in the reform: they have been implemented after more than 20 years to replace the relevant provinces in some regions. Being quite peculiar and not comparable with the Spanish case, this will not be considered in the analysis.
} 
Table 1. Three propositions and relevant articulation and their expected effects

\begin{tabular}{lc}
\hline \hline Propositions & Expected effects \\
\hline P1: Increased financial restrictions lead to higher constraints for local & \\
government ... the more likely a & \\
P1a: the greater the cuts (amount in euros) ... & Decrease in local (fiscal) \\
P1b: the stricter the limit for local expenditure (annual budget) ... & discretion \\
P2: Increased hierarchical controls lead to smaller leeway for local & \\
government ... the more likely a & \\
P2a: the higher the number and extent of re-centralized tasks ... & $\begin{array}{c}\text { Decrease of local } \\
\text { (administrative) discretion }\end{array}$ \\
P2b/P2c: the higher the number and extent of new procedural and & $\begin{array}{c}\text { Increase in central legal } \\
\text { regulation }\end{array}$ \\
financial controls ... & $\begin{array}{c}\text { P3: Increased reduction of options leads to smaller-scale choice range for } \\
\text { local government ... the more likely a }\end{array}$ \\
P3a: the higher the number and extent of bans ... & $\begin{array}{c}\text { Decrease in local } \\
\text { (functional) discretion } \\
\text { P3b: the more detailed the normative prescriptions on organizational } \\
\text { matters ... }\end{array}$ \\
$\begin{array}{l}\text { P3c: the more explicit and reduced the number and extent of choices on } \\
\text { local government forms ... }\end{array}$ & administrative regulation \\
\hline \hline
\end{tabular}

Source: Author's compilation.

The second indicator (administrative discretion) concerns the role of central controls: hierarchical controls may imply that certain tasks, previously transferred to local authorities, are (re)assigned to central authorities. They may also bring an increase in procedural and normative checks or the supervision of activities at the local level, including the financial performance of local bodies.

As for functional discretion, some provisions may imply proscriptions for local authorities (for instance, in terms of personnel, positions, or supporting bodies/ organs), whereas other provisions may impose detailed guidelines in terms of their organization and functioning. The last articulation brings indirectly forward the topic of territorial reform: we would expect that where the options for creating, renewing, or organizing a local or intermediate authority are explicit and circumscribed, these authorities are more likely to suffer a restriction in their functional discretion.

Table 1 summarizes these ideas in the form of three propositions, together with their expected effects.

Should these propositions (and relevant articulation) be confirmed for Italy and Spain in an appropriate time frame, it would be possible to argue that there is empirical evidence of a change in local discretion - and thus in central legal regulation provoked by crisis-driven reforms. However, as noted earlier, the only data that are currently available are qualitative and provisional, mainly due to the uncertain fate of some of these reforms and their recent (and in some cases partial) implementation. 
It would be hazardous to generalize from this limited set of evidence. The time span under consideration will cover the years of the crisis, focussing on the period between 2010 and 2014.

\section{A qualitative assessment of change in local discretion in Italy and Spain}

This section will provide a first assessment of the impact of both directly and indirectly crisis-driven provisions on local governments in Italy and Spain and on the three main facets of local discretion. We will analyse normative acts (mainly laws, decree laws, and draft law) and existing literature, as well as drawing on interviews with key witnesses (about 60 civil servants at local level and academic experts) conducted during field research in Italy and Spain, between 2011 and 2013, within the framework of a research project funded by the Italian Ministry of Education.

\section{Financial restrictions and fiscal discretion}

Let us start with fiscal discretion and the role of financial restrictions. Both reductions in transfers (or grants) from central authorities to local levels and cuts in local government expenditures will be considered. Although both grants and expenditures are already somewhat constrained by higher levels of government, including the EU, and are not a direct or unique indicator of the freedom of local governments to act and take decisions (Dexia, 2008: 7-8) - let alone 'good' decisions - their reduction may significantly limit the discretion of local authorities.

Local revenues and expenditures vary from one European country to another. The following data, based on Dexia and Eurostat reports, encompass both regional and local levels. They are used here to provide a rough idea of economic and financial trends (and to support the inclusion of this aspect in the analysis) with no intent of providing a technical discussion. On average, the EU sub-national public sector revenues rose for about a decade (2000-09), with grants (mostly state transfers) being the main source of these total revenues (rising between 2005 and 2010 from 37 to 46\%) (Dexia, 2008, 2011, 2012). In Italy and Spain, state transfers accounted, respectively, for around 47 and 37\% in 2011 (Dexia, 2012: 15). In 2010, local revenues dropped in volume, inverting this trend, because grants were frozen or even withheld (Dexia, 2011). Transfers to local levels dropped in the EU by an average of $4.9 \%$ in 2010 , although 2009 was a year of widespread stimulus packages. In the two countries, sub-national public sector revenues decreased in 2010 and 2011 by 5 and $3 \%$ in Italy and by $10 \%$ and by $>8 \%$ in Spain (Dexia, 2011: 7, 2012: 12-15).

Sub-national expenditures account for about a third of total public expenditure in Europe, but this figure encompasses very different situations: although Italy is in line with the EU average (about 30\%), Spain is a more decentralized state where sub-national expenditure exceeds $50 \%$ of the total. Local expenditures followed the 
same trend as state transfers: after a steady increase since the 1970s and a decade of sustained growth including 2008-09, which were marked by stimulus plans driven by the crisis, spending in nearly all EU member states declined after 2010 (Dexia, 2011, 2012). Both Italy and Spain passed constitutional amendments to adopt the fiscal compact and the balanced-budget provisions required by the new EU economic governance (Marti del Moral, 2012; Morgante, 2012). This decision brought with it a series of stringent financial measures, which meant severe cuts to local budgets. A comparative survey analysis (Bouckaert et al., 2010) has shown that the most common crisis-induced reactions were initiatives that limited the expenditures (e.g. by postponing investment or by directly cutting budgets), followed by indirect savings (e.g. by decreasing government staff numbers). Local authorities were, thus, forced to tighten their budget so that their current, financial, and personnel expenses plummeted: Italy and Spain reduced overall local expenditures by around 3-4\% (Dexia, 2011: 10-12).

This shift is evident when one examines cuts in transfers/grants $(P 1 a)$ : in Italy, hard financial cuts in state transfers to local bodies, proportionate to their population, were implemented in 2009 and 2010, and sharp cutbacks were announced for subsequent years so that [according to the estimates of General Accounting (Ragioneria Generale dello Stato, 2013, 2014)] overall money allocations were reduced. True, a mixed effect of domestic laws (e.g. the reintroduction in 2012 of the previously abolished municipal property tax, coupled with a residence tax under a single municipal tax) and EU-driven austerity measures contributed to this effect (Dexia, 2012: 12), but the reduction in grants was, nevertheless, drastic. Cutbacks for local governments, in particular, amounted to 5.8 and 7.5 billion euros for 2011 and 2012, respectively, and these savings were obtained by reducing state transfers (Pola, 2010: 8-9). An emergency economic measure approved in Summer 2011 (Law 148/2011 named Summer measures), reinforced by another law (Law 214/2011 named Rescue Italy) some months later, imposed a cut in state financial transfers to local governments, with particularly negative effects on social services and infrastructures (Gardini, 2011: 458). These provisions led to a drop of around eight billion euros in transfers to local and regional levels compared with 2010 (Dexia, 2012: 16).

In Spain, stimulus measures were taken both by the Spanish central state and by the different ACs at the beginning of the crisis (2008-09). Since early 2010, however, harsh austerity measures have been applied (Viver, 2011: 163ff.). The local representatives interviewed indicated that cutbacks in transfers were implemented in a significant way in relation to every possible source. With budget cuts at all levels, the effects of these austerity measures rebounded on local bodies: some interviewees stated that EU funds, previously transferred to ACs and the central state, have been diminishing in recent years, with the effect that transfers to local authorities have also been reduced, and these local bodies, without financial aid, can no longer afford to provide certain services to the citizens. Among member states, state transfers declined most dramatically in Spain $(-30.3 \%)$ between 2010 
and 2011 (Dexia, 2012: 16). Transfers provided to local governments until 2009 had the effect of reinforcing the relationship between local governments and the central state to the detriment of ACs (Viver, 2011: 172), weakening one of the pillars of Spanish decentralization, as a local government is constitutionally an exclusive competence of ACs.

The introduction of spending limits $(P 1 b)$, however, has been the most restrictive measure for public administration budgets. The implementation of EU agreements and revision of the Stability and Growth Pact through the Sixpack also implied a ceiling to expenditure at central and local levels. Local governments are now subject to the same fiscal discipline as the central state (Garcia-Andrade, 2012: 300, 310; Morgante, 2012: 27). In any case, budget parameters established by the EU to achieve spending targets force all municipalities to stay within deficit limits - the only discretion being to choose which budget item should be reduced (Viver, 2011: 166) (almost always social expenditures) - without any opportunity to bargain about the distribution of cuts (Pola, 2010: 8). In this context, it is worth mentioning the agreement signed between Spain and the EC to reduce the total public deficit of the state, ACs, and local governments by $8.5 \%$ in 3 years (from $11.5 \%$ in 2009 to $3 \%$ in 2013). This decision was taken in 2010 , without previous agreement with local authorities, contravening existing laws (Viver, 2011: 166).

In Spain, the current spending of the public administration was cut by about $10 \%$ at all levels through the suppression of positions, bodies, companies, and agencies in 2010-11 (Viver, 2011: 167). In 2010, a freeze was also imposed in Italy on the renewal of contracts for civil servants, recruitment, wages, and careers (Law 122/2010). In Spain, local authorities were prohibited from using any type of longterm public or private credit to finance their investments, even if this prescription was later modified to allow access to credit within a given level of debt (Viver, 2011: 167-168). In Italy, a limit on net indebtedness for investments was imposed on provinces and municipalities with $>5000$ inhabitants in 2008 and strengthened in 2012 (Law 112/2008 implementing the Stability Pact for 2009-11 and Law 183/2011, which was later integrated by Law 243/2012 to implement the new constitutional limits on balanced budgets).

In both countries, all norms regarding personnel are now subject to the balancedbudget rules. Therefore, limits on turnover in the public sector - set at $20 \%$ of retirements in Italy and 10\% in Spain - have been imposed at both central and local levels. Moreover, in Spain, strict norms on civil servants have been imposed on ACs, thus leaving them, and their relevant local authorities, only the possibility to choose how to distribute cuts, but not their entity (Viver, 2011: 174). Another form of direct cuts in both countries has affected local representatives. In Italy, the suppression of the executive body (Giunta) of the provinces and a reduction in the number of representatives on provincial councils aimed to reduce public positions, and thus save money. Similarly, there has been a reduction in the number of local representatives and executive members of about $20 \%$ for all municipalities and provinces, with most local positions being unpaid. Even more drastically, the 
Spanish local government reform has suppressed remuneration for about $82 \%$ of current local administrators (starting in July 2015), set a limit (according to population size) on mayors' and provincial presidents' emoluments, and significantly reduced the number of local representatives in elected bodies as well as the number of elected and nominated executive members.

\section{Hierarchical control and administrative discretion}

In both countries, there is empirical evidence supporting the claim of re-centralized tasks $(P 2 a)$. This most notably concerns municipal civil servants and their roles. In Italy, the municipal and county clerk (or secretary) is a key position, especially in smaller municipalities: clerks cover a remarkable range of functions, being in charge of controlling (or directly executing) all activities of the municipality. In the 1990s, this figure had gained more autonomy from the Ministry of the Interior (until then, clerks had been selected and employed by the Ministry): an independent agency was created and they could then be selected and appointed directly by the mayor. In 2010, however, this position was brought back under the direct control of the Ministry, and the aforementioned agency was abolished (Vandelli, 2012a: 338-339). In Spain, municipal clerks have been reinforced by the new provisions and their controlling role dramatically increased (Law 27/2013). Municipal clerks who usually carried out an ex post control role - are now charged with supervision and inspection functions. This may even imply opportunity supervision on local activities as well as the possibility of 'reporting' a non-compliant municipality to the Court of Auditors. However, above all, these civil servants now respond directly to the Ministry, rather than to the municipality, regarding their daily secretarial, supervision, and treasury functions.

As for new procedural $(P 2 b)$ and financial controls $(P 2 c)$, these directly derive from recent EU agreements. The 2011, Sixpack and balanced-budget rules formally set out increased controls (both procedurally and financially), which had to be implemented by each state, implying a necessary reinforcement of central controls over local governments (Dickmann, 2013) and an increase in performance evaluation.

In Spain, Law 27/2013 states that 'in order to achieve more rigorous budget control, the supervision function (función interventora) over local authorities is reinforced and central government is entitled to fix rules on control procedures, implementation methods and criteria, as well as on rights and duties in exerting control functions'. The central government must control the legal and financial compliance of municipalities according to the newly introduced calculations of the cost of local public services. Our interlocutors complained that central administration, through ministerial or Ministry-dependent inspections, has multiplied its controls and is 'looking for scapegoats' by reviewing all past state and regional transfers (dating back 5-6 years) and subventions to local bodies in a search for procedural, legal, and/or financial mismanagements, errors, and failures with the 
aim of taking the money back. Many auditing and bureaucratic procedures are required in order to pass these new controls and almost all municipalities are constantly audited. Since the end of 2010, ACs and local governments have to present their balanced-budget plans to the central state, and all local entities must also provide central auditing and supervising authorities with a detailed budget along with debt reports and all expenditure documents every 3 months (previously it was yearly).

In Italy, a similar path has been defined, based on a dramatically enhanced role of the State Court of Auditors, beginning with the constitutional review in 2001, but increasing in 2009-11 (Allegretti, 2013), and with the constitutional amendment on balanced budgets (Gambino, 2013; Morgante, 2013). This progressive empowerment was driven by the need to constantly verify the use of public resources in times of crisis and shrinking budgets. However, it actually reversed the trend that had characterized Italy over the previous decade - that is, a reduction of external controls over local authorities - bringing back, by contrast, a 'jungle of controls' (Vandelli, 2013: 249).

\section{Reduction of options and functional discretion}

Empirical evidence of a change in the leeway and discretion of local authorities can be detected in relation to each of the aspects summed up by our propositions. For example, some bans for local governments $(P 3 a)$ have been introduced. Italy is a good example of the reduction (or removal) of municipal agencies or other bodies that exert basic municipal functions (Piperata, 2012: 517-518): municipalities are now banned from creating agencies that carry out such functions. In Spain, similar constraints are found, and municipalities are no longer entitled to issue licences for economic activities and cannot create any type of municipal agency or enterprise (Ministerio-de-Hacienda-y-Administraciones-Publicas, 2013: 6). As presented before, strict rules on personnel turnover, determined by the Stability and Growth Pact and its recent revisions, now effectively prevent local authorities in both countries from employing new civil servants.

In Italy, city-districts (circoscrizioni) have been suppressed for cities below 250,000 inhabitants, whereas in Spain something similar has occurred with the infra-municipal entities (Eatimes), which are now subject to the same rigid financial discipline as their respective municipalities and suppressed in case of non-compliance. The disappearance in Italy of several local administrative positions, which had been introduced in the previous decade, can be included with these reductions of available options. The most significant of these is the municipal Ombudsman, which now survives only at the provincial level (Borgonovo Re, 2012: 410-414). The managerial position of the Director General has also been suppressed: it was created in order to have a more flexible and managerial local government, and this position was an important instrument of differentiation and autonomy for mayors and municipalities (Vandelli, 2012a: 339-340). 
Establishing directives on organizational matters $(P 3 b)$ could open possibilities for central authorities to directly participate in the 'everyday life' of local levels of administration and, most of all, interfere with their statutory autonomy. The best example, as far as Italy is concerned, is the governmental provision that determines even the suggested times to convene municipal council meetings (not overlapping with working hours) (Vandelli, 2012b). In Spain as well, some anti-crisis state provisions have augmented, sometimes indirectly, the role of the central government in relation to the organization of local bodies (Viver, 2011: 174), for example, through the decision on new (reduced) wage levels for the employees of ACs and local authorities.

Finally, forced choices regarding the forms of local governments $(P 3 c)$ have been imposed in both Italy and Spain during the years of crisis. In Italy, local levels could freely choose forms of inter-municipal cooperation until the mid-2000s, and the regional government was the only level with any say in this matter. Since the crisis, the national government has intervened directly in relation to this in a non-negotiable way, which has also triggered constitutional disputes (Vandelli, 2013: 91). For instance, norms have been approved since 2010 with the aim of (at least partially) solving the small municipalities' inefficiencies. The most recent example is Law 56/2014, which obliges small municipalities (with $<5000$ inhabitants) to manage their compulsory basic tasks (e.g. administration, police, school, transports, territory management, social care) through an inter-municipal form. If we consider that $>70 \%$ of the over 8000 Italian municipalities have $<5000$ inhabitants (2015), it is obvious that this provision could have a significant impact on the discretion of the majority of Italian local administrations in carrying out these tasks. Moreover, from a range of several inter-municipal options, the choice was reduced to just one (the Municipal Unions - Unioni di comuni). As a consequence, their number notably increased, swelling from 271 in 2006 to over 400 in early 2015, whereas other forms of inter-municipality were dismantled.

In Spain, the reform introduced by Law 27/2013 on the rationalization and sustainability of local administration brought with it two major changes. First, the province is entitled to coordinate the provision of public services, directly or through an inter-municipality, for all municipalities with $<20,000$ inhabitants, at a cost complying with the effective cost of the service established by the State Ministry. Considering that municipalities with $<20,000$ inhabitants account for over $95 \%$ of the 8117 Spanish municipalities, the magnitude of this provision is self-evident. The second novelty concerns inter-municipality: existing Municipal Unions (Mancomunidades) must submit their budgets and financial reports to auditing central authorities such as municipalities and all other local authorities. Those resulting to be non-compliant will be suppressed. All in all, intermunicipalities are quite penalized by this reform. All Municipal Unions must now conform their Statutes to the new law and reformed municipal tasks. This implies far-reaching adaptations for many of them, and the disappearance of many others, such as those devoted to economic and social development (Lucas, 2014: 188) or to generic tasks (the majority fall into this category). 


\section{Conclusion: crisis-driven reforms, local discretion, and central/local relations}

As we have shown, both directly and indirectly, crisis-related reforms have induced comprehensive changes in the three main facets of local discretion: financial, administrative, and functional. Although these changes may have been expected, they have restricted the discretion of local governments. The results of this exploratory assessment thus allow us to affirm that there is empirical support for the propositions' core statements (P1, P2, and P3) - respectively, focussed on empirical aspects of fiscal, administrative, and functional discretion - as outlined in the previous paragraph and as summarized in the following Table 2.

This evidence, although collected only a short time after the reforms/provisions were implemented, nonetheless, already allow us to reach some provisional conclusions.

First, it transpires that austerity measures, introduced with the aim of curbing public spending, have been the main driving force behind crisis-led provisions. This priority brought with it an overall disregard for other possible effects. True, these structural consequences may have been unintended, probably due to the limited time span in which the provisions were approved in order to face the sovereign debt crisis, reducing the possibility of in-depth analysis and discussion. In any case, budgetary goals have had a more systemic effect than provisions to merely contain expenditure, as they affect the very functioning of local governments.

In addition, in fact, both directly (austerity measures) and indirectly (territorial reforms) crisis-led provisions have had dramatic effects on the central/local relations. All normative novelties introduced in the years of crisis have had a negative impact on the discretion of local governments. Local governments in Italy and Spain have suffered financial cuts, controls, and diminishing options. There has been a generalized decrease in the capacity of local levels to make decisions about the type of services they deliver and about how they should be provided and financed as well as a reduction in local influence over national policies with local effects. At the same time, there has been an increase in legal and administrative regulations, creating wider margins for central involvement in local life and more possibilities to limit local discretion.

The reactions of local governments in both the countries have been fierce and political debate has been harsh. In some respects, several local issues have been taken on board by the centre. ${ }^{4}$ Despite this attempt at balancing, administrative geography has been fundamentally re-mapped, within the context of a far-reaching shift in competences and powers between the central and local levels in both the countries.

\footnotetext{
${ }^{4}$ Both in Italy and in Spain, local authorities addressed the relevant Supreme Court against a number of crisis-led and austerity-driven national provisions. For example, Spanish Law 27/2013 turned out to be significantly different (and remarkably softer in terms of constraints on local authorities) after municipalities appealed the Court (Santamaria, 2014). In Italy, a provision that would have abolished some local governments and re-mapped the local administrative geography was declared illegitimate by the Court and was blocked after a number of regions and local authorities appealed against it in 2013 and 2014.
} 
Crisis-driven reforms and local discretion 87

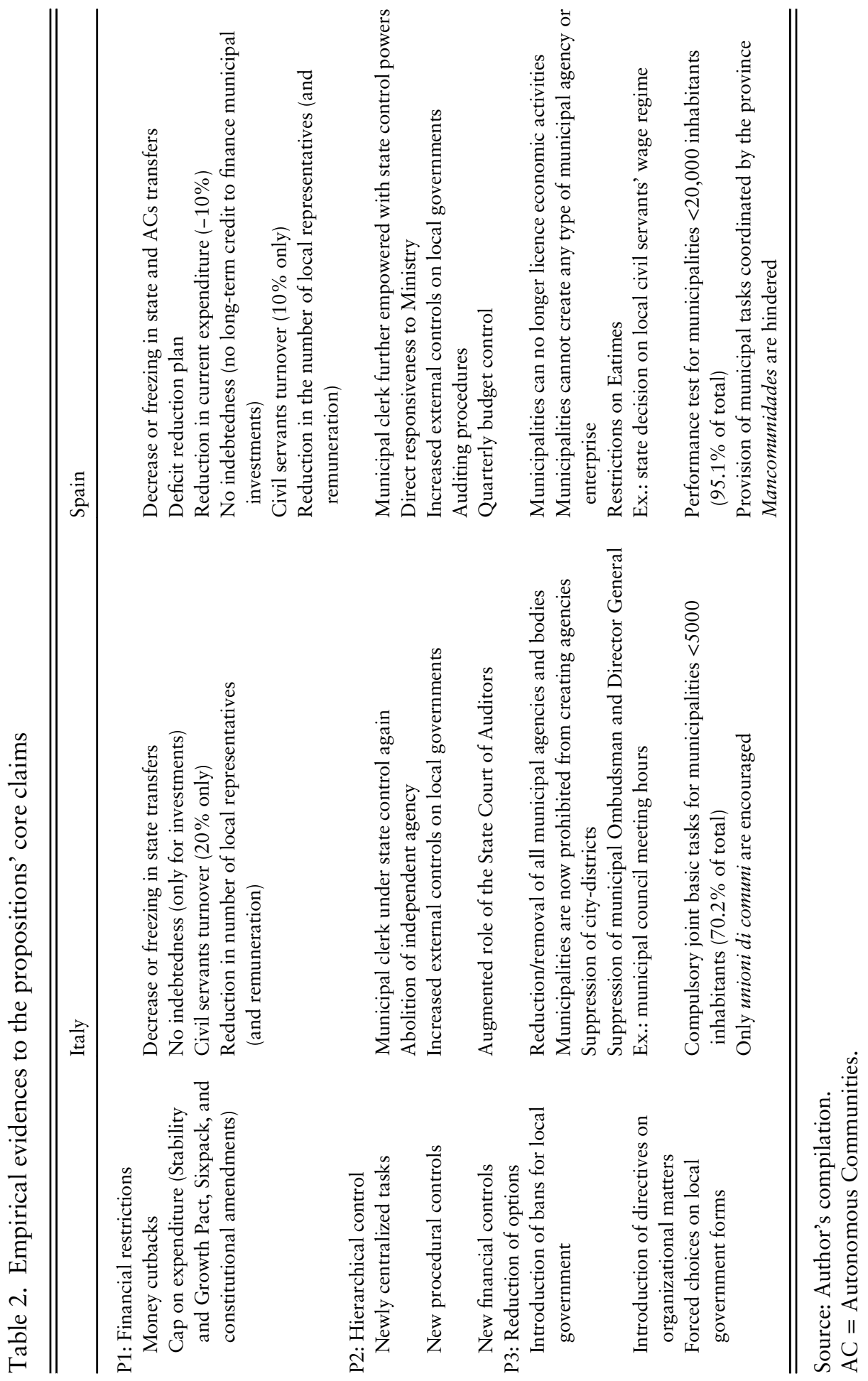


Whether this will have a restrictive impact on self-government and the principle of autonomy remains to be seen, but there are already some hints in this direction, and these debates seem destined to continue as the implications of the provisions introduced in the crisis years are likely to be long lasting.

\section{Acknowledgements}

The author thanks the anonymous referees for their valuable comments, which considerably improved this article. The research has been funded by the Italian Ministry for Research and Higher Education, Prin 2009 (funded 2011-13) 'Nuove forme di governance locale come strumento di sviluppo strategico del territorio. Una ricerca comparata in sei regioni europee'.

\section{References}

Agranoff, R. (2004), ‘Autonomy, devolution and intergovernmental relations', Regional \& Federal Studies 14(1): 26-65.

Aja, E. (2001), 'Spain: nation, nationalities, and regions', in J. Loughlin (ed.), Subnational Democracy in the European Union: Challenges and Opportunities, Oxford: Oxford University Press, pp. 229-254.

— (2003), El estado autonomico. Federalismo y hechos diferenciales, 2nd edn., Madrid: Alianza.

Allegretti, U. (2013), 'Controllo finanziario e Corte dei conti: dall'unificazione nazionale alle attuali prospettive', Rivistaaic.It 1: 1-18.

Armingeon, K. (2012), 'The politics of fiscal responses to the crisis of 2008-2009', Governance 25(4): $543-565$.

Baldi, B. (2003), Stato e territorio. Federalismo e decentramento nelle democrazie contemporanee, Bari-Roma: Laterza.

Bennett, R.J. (ed.) (1993), Local Government in the New Europe, London/New York: Belhaven.

Beramendi, P. and R. Maiz (2004), 'Spain. Unfulfilled federalism (1978-1996)', in U. Amoretti and N. Bermeo (eds), Federalism and Territorial Cleavages, Baltimore, MD: Johns Hopkins University Press, pp. 123-154.

Berman, D.R. and L.L. Martin (1988), 'State-local relations: an examination of local discretion', Public Administration Review 48(2): 637-641.

Bobbio, L. (2002), I governi locali nelle democrazie contemporanee, Bari-Roma: Laterza.

Bolgherini, S. (2014), 'Can austerity lead to recentralisation? Italian local government during the economic crisis', South European Society and Politics 19(2): 193-214.

Borgonovo Re, D. (2012), 'Italia: la reforma del sistema provincial', in L. Cosculluela and L. Medina (eds), Crisis económica y Reforma del Régimen Local, Madrid: Civitas, pp. 393-414.

Bosco, A. and S. Verney (2012), 'Electoral epidemic: the political cost of economic crisis in Southern Europe 2010-11', South European Society and Politics 17(2): 129-154.

Bouckaert, G., J. Voets and D. De Herdt (2010), Local government in the EU at a glance: survey analysis. Leuven: Public Management Institute \& Policy Research Centre on Governmental Organization in Flanders.

Cosculluela, L. and L. Medina (eds) (2012), Crisis económica y Reforma del Régimen Local, Madrid: Civitas.

Dente, B. (1985), 'Intergovernmental relations as central control policies: the case of Italian local finance', Environment and Planning C 3(4): 383-402.

Denters, B. and L.E. Rose (eds) (2005), Comparing Local Governance. Trends and Developments, New York, NY: Taylor \& Francis. 
Dexia (2008), Sub-National Governments in the European Union: Organisation, Responsibilities and Finance, La Défense: Dexia Editions.

Dexia (2011), Subnational Public Finance in the European Union. Report July 2011, La Défense: Dexia Editions.

Dexia (2012), Subnational Public Finance in the European Union. Report Summer 2012, La Défense: Dexia Editions.

Diamanti, I. (2003), 'Il ritorno dello Stato. L'Italia, dal regionalismo al neocentralismo', in P. Messina (ed.), Sistemi locali e spazio europeo, Roma: Carocci, pp. 228-245.

Dickmann, R. (2013), Governance economica europea e misure nazionali per l'equilibrio dei bilanci pubblici, Napoli: Jovene.

Dinan, D. (2012), 'Governance and institutions: impact of the escalating crisis', Journal of Common Market Studies 50(Suppl 2): 85-98.

Dyson, K. (2012), “"Maastricht Plus”: managing the logic of inherent imperfections', Journal of European Integration 34(7): 791-808.

- (2013), 'Sworn to grim necessity? Imperfections of European economic governance, normative political theory, and supreme emergency', Journal of European Integration 35(3): 207-222.

Fabbrini, S. (2013), 'Intergovernmentalism and its limits assessing the European Union's answer to the euro crisis', Comparative Political Studies 46(9): 1003-1029.

Gambino, S. (2013), 'Controlli e autonomie territoriali fra (potenziamento delle funzioni della) Corte dei conti, legislazione (di riequilibrio finanziario) e giurisprudenza costituzionale', Federalismi.it 17: $1-38$.

Garcia-Andrade, J. (2012), 'La aplicacion del principio constitucional de estabilidad presupuestaria a las entidades locales', in L. Cosculluela and L. Medina (eds), Crisis económica y Reforma del Régimen Local, Madrid: Civitas, pp. 293-325.

Gardini, G. (2011), 'Le autonomie ai tempi della crisi', Istituzioni del Federalismo XXXII(3): 457-466.

Goldsmith, M.J. (1992), 'Local government', Urban Studies 29(3-4): 393-410.

Goldsmith, M.J. and E.C. Page (eds) (2010), Changing Government Relations in Europe: From Localism to Intergovernmentalism, Abingdon: Taylor \& Francis.

Hesse, J.J. and L.J. Sharpe (1991), 'Local government in international perspective: some comparative observations', in J.J. Hesse (ed.), Local Government and Urban Affairs in International Perspective, Baden-Baden: Nomos, pp. 603-620.

Hooghe, L., G. Marks and A.H. Schakel (2010), The Rise of Regional Authority: A Comparative Study of 42 Democracies, Abingdon: Routledge.

Hulst, R. and A. Van Montfort (eds) (2007), Inter-Municipal Cooperation in Europe, Dordrecht: Springer.

Irujo, A. (2012), 'Crisis económica y reforma local', in L. Cosculluela and L. Medina (eds), Crisis económica $y$ Reforma del Régimen Local, Madrid: Civitas, pp. 49-74.

Istituzioni del Federalismo (2011), 'Le autonomie ai tempi della crisi', Istituzioni del Federalismo XXXII (3, special issue): 457-704.

Istituzioni del Federalismo (2012), 'La razionalizzazione del sistema locale in Italia e in Europa', Istituzioni del Federalismo XXXIII (2, special issue): 503-764.

Jones, E. (2012), 'The Berlusconi government and the sovereign debt crisis', in A. Bosco and D. McDonnell (eds), Italian Politics: From Berlusconi to Monti, Oxford: Berghahn, pp. 172-190.

Kamkhaji, J.C. and C.M. Radaelli (2013), 'The emerging governance architecture of the eurozone', Rivista Italiana di Politiche Pubbliche 8(2): 199-220.

Keating, M. (1995), 'Size, efficiency and democracy: consolidation, fragmentation and public choice', in D. Judge, G. Stoker and H. Wolman (eds), Theories of Urban Politics, London: Sage, pp. 117-134.

- (1998), The New Regionalism in Western Europe: Territorial Restructuring and Political Change, Cheltenham: Edward Elgar.

Keeler, J.T. (1993), 'Opening the window for reform mandates, crises, and extraordinary policy-making', Comparative Political Studies 25(4): 433-486.

Kersting, N. and A. Vetter (2003), Reforming Local Government in Europe: Closing the Gap Between Democracy and Efficiency, Wiesbaden: VS Springer. 
Lippi, A. (2011), "Evaluating the "quasi federalist" programme of decentralisation in Italy since the 1990s: a side-effect approach', Local Government Studies 37(5): 495-516.

Losada, A. and R. Maiz (2005), 'Devolution and involution: de-federalization politics through educational policies in Spain (1996-2004)', Regional and Federal Studies 15(4): 437-451.

Loughlin, J. (2001), Subnational Democracy in the European Union: Challenges and Opportunities, Oxford: OUP.

Loughlin, J., F. Hendriks and A. Lidström (eds) (2010), The Oxford Handbook of Local and Regional Democracy in Europe, Oxford: OUP.

Lucas, C. (2014), 'El problema de la planta local. las entidades inframunidpales y supramunicipales', in J.A. Santamaria (ed.), La reforma de 2013 del regimen local espanol, Barcelona: Fundacion Democracia y Gobierno Local, pp. 173-191.

Maiz, R., P. Beramendi and M. Grau (2002), 'La federalizacion de Estado de las Autonomias: evolucion y déficit institucionales', in J. Subirats and R. Gallego (eds), Veinte anos de autonomias en Espana, Barcelona: CIS, pp. 379-424.

Maiz, R., F. Caamaño and M. Azpitarte (2010), 'The hidden counterpoint of Spanish federalism: recentralization and resymmetrization in Spain (1978-2008)', Regional \& Federal Studies 20(1): 63-82.

Mangiameli, S. (2013), Le Regioni italiane tra crisi globale e neocentralismo, Roma: Giuffré.

Marti del Moral, A. (2012), 'La constitucionalizacion del principio de estabilidad presupuestaria', in L. Cosculluela and L. Medina (eds), Crisis económica y Reforma del Régimen Local, Madrid: Civitas, pp. 271-291.

Medina, M. (2014), La reforma del regimen local, Valencia: Tirant Lo Blanch.

Ministerio-de-Hacienda-y-Administraciones-Publicas (2013), Reforma para la racionalizacion y sostenibilidad de la administracion local. Madrid: Ministerio-de-Hacienda-y-Administraciones-Publicas.

Moreno, A.-M. (2012a). Local government in Spain', in A.-M. Moreno (ed.) Local Government in the Member States of the European Union: A Comparative Legal Perspective, Madrid: INAP, pp. 573-612.

- (2012b). La administracion local desde la perspectiva europea: autonomia y reformas locales', El Cronista 27: 84-90.

Morgante, D. (2012), 'La costituzionalizzazione del pareggio di bilancio', Federalismi.it 14: 1-42.

— (2013), 'Controlli della Corte dei conti e controlli regionali: autonomia e distinzione nella sentenza della Corte costituzionale n. 60/2013', Federalismi.it 9: 1-24.

Moschella, M. and E. Tsingou (eds) (2013), Great Expectations, Slow Transformation: Incremental Change in Financial Governance, Colchester: ECPR Press.

Nanetti, R.Y. (1988), Growth and Territorial Politics, London/New York: Pinter.

Nieto, E. (2007), 'Inter-municipal cooperation in Spain: dealing with microscopic local government', in R. Hulst and A. van Montfort (eds) Inter-Municipal Cooperation in Europe, Dodrecht: Springer, pp. 169-192.

Page, E.C. (1991), Localism and Centralism in Europe: The Political and Legal Bases of Local Self-Government, Oxford: Oxford University Press.

Page, E.C. and M.J. Goldsmith (1985), 'Centralisation and decentralisation: a framework for comparative analysis', Environment and Planning C 3(2): 175-185.

Page, E.C. and M.J. Goldsmith (eds) (1987), Central and Local Government Relations: A Comparative Analysis of Western European Unitary States, London: Sage.

Perulli, P. (2010), 'Politiche locali tra decentralizzazione e ricentralizzazione', Stato e mercato 3: 365-394.

Peters, B.G., J. Pierre and T. Randma-Liiv (2011), 'Global financial crisis, public administration and governance: do new problems require new solutions?’, Public Organization Review 11(1): 13-27.

Piperata, G. (2012), 'I poteri locali: da sistema autonomo a modello razionale e sostenibile?', Istituzioni del Federalismo XXXIII(3): 503-522.

Pola, G. (2010), 'Italy out of the crisis: more centralized or federated?'. Paper presented at the Conference Federalism and the Global Financial Crisis: Impact and Responses, September 16-18, Philadelphia, PA and Camden, NJ.

Ragioneria Generale dello Stato (2013), Le manovre di finanza pubblica del 2012, Roma: Ministero Economia e Finanze. 
Ragioneria Generale dello Stato (2014), La manovra di finanza pubblica per 2014-2016, Roma: Ministero Economia e Finanze.

Rhodes, R.A.W. (1981), Control and Power in Central-Local Government Relations, Aldershot and Brookfield, VT: Gower and Ashgate.

Robinson, J.A. (1968), 'Crisis', in D.L. Sills and R.K. Merton (eds), International Encyclopedia of Social Sciences, New York, NY: Macmillan, pp. 510-514.

Royo, S. (2009), 'After the fiesta: the Spanish economy meets the global financial crisis', South European Society and Politics 14(1): 19-34.

Santamaria, J.A. (ed.) (2014), La reforma de 2013 del regimen local espanol, Barcelona: Fundacion Democracia y Gobierno Local.

Sharpe, L.J. (1979), Decentralist Trends in Western Democracies, London: Sage.

Sharpe, L.J. (ed.) (1993), The Rise of Meso-Government in Europe, London: Sage.

Swianiewicz, P. (ed.) (2010), Territorial Consolidation Reforms in Europe, Budapest: OSI/LGI.

Vandelli, L. (2012a). 'Local government in Italy', in A.-M. Moreno (ed.), Local Government in the Member States of the European Union: A Comparative Legal Perspective, Madrid: INAP, pp. 327-350.

— (2012b). 'Enti locali. Crisi economica e trasformazioni del governo locale', L'enciclopedia italiana - Treccani.it, Roma: Treccani, pp. 1-5.

- (2013), Il sistema delle autonomie locali, 5th edn., Bologna: Il Mulino.

Viver, C. (2011), 'L'impacte de la crisi econòmica global en el sistema de descentralització política a Espanya', Revista d'Estudis Autonòmics i Federals 13: 146-185.

Wollmann, H. (2008), Comparing Local Government Reforms in England, Sweden, France and Germany, Berlin: Wuestenrot Stiftung.

Yilmaz, S., Y. Beris and R. Serrano-Berthet (2008), Local Government Discretion and Accountability: A Diagnostic Framework for Local Governance, Washington, DC: World Bank.

Zimmerman, J.F. (1981), Measuring Local Discretionary Authority, Washington, DC: Advisory Commission on Intergovernmental Relations. 